\title{
ANALISIS SURAT DINAS YANG DITULIS SISWA KELAS XI SMK PAB 3 MEDAN ESTATE
}

\author{
Enny Rahayu, S.Pd., M.Hum. \\ Fakultas Keguruan dan Ilmu Pendidikan UMSU \\ enny_wisman@yahoo.co.id
}

\begin{abstract}
Abstrak
Penelitian ini berangkat dari tiga masalah, yakni (1) bagaimana kelengkapan bagaian-bagian surat dinas yang ditulis siswa SMK PAB 3 Medan Estate; (2) bagaimana ketepatan penulisan bagian-bagian surat dinas yang ditulis siswa SMK PAB 3 Medan Estate? (3) kesalahan apa saja yang terdapat dalam surat dinas yang ditulis siswa SMK PAB 3 Medan Estate? Tujuan penelitian ini adalah untuk mendeskripsikan kelengkapan bagian-bagian surat, mendeskripsikan ketepatan bagianbagian surat, dan kesalahan-kesalahan yang terdapat dalam surat dinas yang ditulis siswa SMK PAB 3 Medan Estate. Penelitian ini merupakan penelitian deskriptif. Data dalam penelitian ini bersumber dari 30 naskah surat dinas dan 30 naskah tersebut dibaca secara intensif yang kemudian ditetapkan data berdasarkan pemahaman, pengetahuan, teori sebagai panduan. Kemudian, data dianalisis dengan cara pemaknaan terhadap kelengkapan dan ketepatan, serta pengungkapan kesalahankesalahan umum dalam naskah surat yang ditulis siswa. Setelah itu, dilakukan penarikan simpulan. Hasil penelitian menunjukkan bahwa (1) semua surat yang ditulis siswa sudah memiliki kop, nomor, alamat, isi, penutup, nama penadanda tangan, dan jabatan penanda tangan; sedikit surat yang tidak memiliki tanggal surat; masih ada surat yang tidak memiliki paragraf pembuka dan tanda tangan; (2) ketepatan penulisan bagian surat lebih rendah $(37,78 \%)$ dibandingkan persentase ketidaktepatan $(62,22 \%)$; (3) kesalahan penulisan surat terdapat pada hampir semua bagian, yakni kop, tanggal, lampiran, hal, alamat, salam pembuka, paragraf pembuka, paragraf isi, paragraf penutup, penutup, nama pengirim (penanda tangan), dan tembusan.
\end{abstract}

Kata kunci: surat dinas, bagian, isi, kesalahan, siswa

\section{Pendahuluan}

Salah satu keterampilan berbahasa yang harus dimiliki siswa adalah keterampilan menulis. Keterampilan menulis memiliki berbagai jenis, seperti menulis berita, menulis cerita atau fiksi, menulis teks tertentu, dan menulis surat. Menulis surat pun, di antaranya, bisa berupa menulis surat pribadi dan menulis surat dinas.

Sebagaimana jenis tulisan yang lain, surat dinas terikat dengan konvensi penulisan tertentu. Konvensi itu, di antaranya adalah, format, struktur, dan bahasa surat dinas. Format surat harus dikuasai siswa. Struktur surat dinas atau bagian-bagian surat dinas juga sangat penting dikuasai. Struktur itu diisi oleh isi tertentu yang diikat oleh kaidah penulisan. Selain itu, hal yang sangat penting dikuasai adalah bahasa yang digunakan. Dari segi bahasa ini, surat dinas harus menggunakan ragam bahasa standar (baku), tunduk pada kaidah ejaan, tepat pemilihan katanya, benar penggunaan kalimatnya, runtut paragrafnya, serta sesuai nalarnya. 
Karena tuntutan seperti itu, adakalanya siswa mengalami kesulitan dalam menulis surat dinas. Kesulitan itu terlihat dalam penelitian yang dilakukan ini. Meskipun surat yang ditulis siswa benar dari segi format dan struktur (bagian-bagiannya), surat yang ditulis itu belum dapat dikatakan benar karena harus dilihat unsur-unsur pengisi bagian-bagian itu. Unsur-unsur pengisi bagian itu merupakan substansi yang tidak boleh diabaikan karena isi tersebut mencerminkan pembuat surat. Sebagaimana dikatakan bahwa surat adalah wakil atau duta. Artinya, surat menjadi sosok yang mewakili penulis atau pembuat surat.

Penelitian ini mengkaji 30 buah surat dinas yang ditulis siswa SMK PAB 3 Medan Estate (yang selanjutnya disingkat SMK PAB $3 \mathrm{ME}$ ). Ke-30 surat dinas tersebut dikaji dari segi (1) kelengkapan bagian-bagiannya, (2) ketepatan penulisan bagian-bagian itu (isi), dan (3) kesalahan umum yang terdapat dalam surat tersebut. Hasil penelitian ini bermanfaat bagi guru, terutama guru SMK PAB $3 \mathrm{ME}$, untuk meningkatkan kemampuan siswa, mengantisipasi kesalahan-kesalahan yang dilakukan siswa, dan menunjukkan kesalahankesalahan yang lazim yang dilakukan siswa dalam menulis surat dinas.

Meskipun saat ini manusia sudah masuk dalam dunia virtual (digital), yang ditandai dengan berkembangpesatnya ilmu pengetahuan, teknologi, informasi, dan komunikasi, peran surat tetap tidak tergantikan. Artinya, surat tetap saja dibutuhkan. Hal ini sejalan dengan definisi surat itu sendiri, yakni sebagai sarana komunikasi tertulis untuk menyampaikan informasi, pernyataan, atau pesan kepada pihak lain yang mempunyai keperluan kegiatan tertentu. Dalam konteks ini, surat membawa informasi, pernyataan, atau pesan yang diharapkan informasi itu akan tersampaikan kepada pihak yang dituju oleh penulis surat (lih. Setiawan, dkk., 2009:11).

\section{Kajian Teori}

\subsection{Hakikat Surat Dinas}

Ada sejumlah pendapat terkait dengan surat dinas. Pendapat tersebut disajikan berikut ini. Hasnun (2007:107) menyatakan bahwa surat dinas adalah surat yang diterbitkan oleh kantor-kantor jawatan pemerintahan, yang tidak termasuk dalam jenis surat keluarga, pribadi, atau surat cinta. Karena surat dinas diterbitkan oleh kantor-kantor jawatan pemerintah, Wibowo (2008:19) menekankan bahwa surat dinas menggunakan bahasa serta format surat yang baku.

Lebih rinci dari pendapat di atas, Silmi (2008:249) mengungkapkan bahwa "suratsurat dinas merupakan surat-surat resmi yang di dalamnya menyangkut berbagai hal tentang kedinasan, misalnya: pengangkatan pegawai, kenaikan pangkat, kenaikan gaji, perpindahan pegawai, keputusan pemberhentian karyawan, dan lain-lain”. Lebih lanjut, Subyantoro (2008) menegaskan bahwa surat dinas/resmi adalah surat yang dikirimkan oleh perseorangan atau kantor pemerintah/swasta kepada perseorangan atau kantor pemerintah/swasta yang isinya menyangkut masalah kedinasan. Ciri kedinasan suatu surat tidak hanya ditandai oleh isi dan penulisannya, tetapi juga ditandai oleh bentuk dan segala formalitasnya (kebakuan bahasa, ketepatan ejaan, dan aturan penulisannya). Selanjutnya, Darma dan Kosasih (2009:9-10) mendefinisikan surat dinas sebagai surat yang berisi masalah kedinasan. Surat dinas bersifat resmi. Oleh karena itu, surat dinas sering diidentikkan dengan surat resmi.

\subsection{Bagian-Bagian Surat Dinas}

Perbedaan antara surat dinas dan surat pribadi, misalnya, terletak pada unsur-unsur atau bagian-bagian surat. Bagian-bagian surat dinas jauh lebih kompleks atau lengkap. Bagian-bagian surat dinas itu, menurut Arifin dan Mustakim (2005:34), adalah (1) kepala surat atau kop surat, (2) tanggal surat, (3) nomor surat, (4) lampiran surat, (5) hal surat, (6) alamat yang dituju, (7) salam pembuka, (8) paragraf pembuka, (9) paragraf isi, (10) paragraf 
penutup, (11) salam penutup, (12) tanda tangan, (13) nama penanda tangan, (14) jabatan penanda tangan, (15) tembusan, dan (16) inisial.

Sedikit berbeda dengan Arifin dan Mustakim, Triharjanto (2007:12) menguraikan bagian-bagian surat menjadi (1) kepala surat, (2) tempat dan tanggal, (3) nomor surat, (4) hal, (5) lampiran, (6) alamat dalam, (7) salam pembuka, (8) paragraf pembuka, (9) isi surat, (10) paragraf penutup, (11) salam penutup, (12) tanda tangan, (13) nama dan jabatan penandatangan, (14) tembusan.

Lebih sederhana dari kedua ahli di atas, Darma dan Kosasih (2009:19) merincikan bagian-bagian surat dinas sebagai berikut: (1) kepala surat, (2) tempat, tanggal surat, (3) nomor surat, (4) lampiran, (5) hal, (6) alamat surat, (7) salam pembuka, (8) isi surat, (9) jabatan, (10) tanda tangan, (11) nama terang, (12) nomor induk kepegawaian, (13) tembusan. Dalam penelitian ini, pendapat Arifin dan Mustakim dijadikan acuan utama.

\subsection{Bahasa dalam Surat Dinas}

Fungsi utama surat adalah menyampaikan informasi atau pesan kepada penerima surat. Untuk itu, surat harus komunikatif sehingga surat harus ditulis dengan bahasa yang benar, yaitu sesuai dengan kaidah komposisi atau kaidah karang-mengarang. Kaidah yang terkait dengan surat menyurat meliputi pemilihan kata, pemakaian ejaan, penyusunan kalimat, penyusunan paragraf yang runtut, dan penalaran (lih. Arifin dan Mustakim, 2005). Berikut ini disajikan secara sepintas perihal bahasa dalam surat dinas tersbut.

\section{1) Pemilihan Kata}

Penulisan surat-surat resmi (dinas) perlu memperhatikan pilihan kata yang memenuhi syarat baik atau baku, lazim, dan cermat. Di samping itu, pemakaian ungkapan idiomatik, ungkapan penghubung, atau ungkapan yang bersinonim harus dituliskan dengan benar.

\section{2) Pemakaian Ejaan}

Penulis surat dinas sebaiknya menguasai kaidah-kaidah ejaan yang terdapat dalam buku Pedoman Umum Ejaan Bahasa Indonesia (PUEBI). Pedoman tersebut merupakan prasyarat yang harus diterapkan dalam penulisan surat dinas.

\section{3) Penyusunan Kalimat}

Kalimat-kalimat yang digunakan dalam surat dinas hendaknya berupa kalimat efektif, yaitu kalimat yang sesuai dengan kaidah bahasa, singkat, dan enak dibaca.

4) Penyusunan Paragraf

Gagasan penulis dituangkan dalam surat hendaknya ditata dan diatur sedemikian rupa dalam paragraf-paragraf sehingga gagasan itu mudah dipahami penerima surat. Setiap gagasan disusun dalam satu paragraf yang utuh. Dengan kata lain, gagasan yang sama tidak dituangkan dalam beberapa paragraf. Sebaliknya, beberapa gagasan yang berbeda tidak dituangkan dalam sebuah paragraf yang sama.

\section{5) Penalaran}

Bahasa mencerminkan pikiran. Untuk itu, kacaunya bahasa menunjukkan kacaunya pikiran. Untuk itu, penulis surat harus menata bahasanya dengan apik dan logis sehingga surat yang disampaikan itu terkesan sistematis, runtut, dan logis.

\section{Metodologi}


Penelitian ini merupakan penelitian deskriptif. Subjek penelitian ini adalah 30 buah surat dinas yang ditulis siswa kelas XI SMK PAB 3 ME. Objek penelitian ini adalah kelengkapan struktur surat, ketepatan struktur surat, dan kesalahan-kesalahan yang terdapat dalam surat yang ditulis siswa tersebut. Instrumen penelitian ini adalah peneliti sendiri yang dilengkapi dengan daftar kendali terkait dengan tiga objek penelitian tersebut. Data dalam penelitian ini bersumber dari 30 naskah surat dinas yang dikumpulkan melalui pembacaan intensif dan penetapan data berdasarkan pemahaman, pengetahuan, teori sebagai panduan. Kemudian, data dianalisis dengan cara pemaknaan terhadap kelengkapan dan ketepatan, serta pengungkapan kesalahan-kesalahan umum dalam naskah surat yang ditulis siswa. Setelah itu, dilakukan penarikan simpulan.

\section{Hasil Penelitian dan Pembahasan}

\subsection{Hasil Penelitian}

\subsubsection{Kelengkapan Bagian-Bagian Surat yang Ditulis Siswa Kelas XI SMK PAB 3 ME}

Secara umum surat dinas yang ditulis siswa kelas XI SMK PAB 3 ME sudah memiliki struktur yang lengkap. Hal itu terlihat pada tabel 1 di bawah ini.

\section{Tabel 1: Kelengkapan Bagian-Bagian Surat yang Ditulis}

Siswa Kelas XI SMK PAB 3 ME

\begin{tabular}{|c|c|c|c|c|c|c|c|c|c|c|c|c|c|c|c|c|c|}
\hline \multirow[t]{2}{*}{ No. } & \multirow{2}{*}{$\begin{array}{l}\text { Kode } \\
\text { Siswa }\end{array}$} & \multicolumn{16}{|c|}{ Bagian-Bagian Surat } \\
\hline & & $\mathbf{a}$ & $\mathbf{b}$ & $\mathbf{C}$ & d & $\mathbf{e}$ & $\mathbf{f}$ & g & $\mathbf{h}$ & i & $\mathbf{j}$ & $\mathbf{k}$ & 1 & $\mathbf{m}$ & $\mathbf{n}$ & о & $\mathbf{p}$ \\
\hline 1 & SIS-1 & $\mathrm{V}$ & $\mathrm{V}$ & $\mathrm{V}$ & $\mathrm{X}$ & $\mathrm{V}$ & $\bar{V}$ & $\mathrm{~V}$ & $\mathrm{X}$ & $\mathrm{V}$ & V & $\mathrm{V}$ & $\mathrm{V}$ & $\mathrm{V}$ & $\mathrm{V}$ & $\mathrm{X}$ & $X$ \\
\hline 2 & SIS-2 & $\mathrm{V}$ & $\mathrm{V}$ & $\mathrm{V}$ & $\mathrm{V}$ & $\mathrm{V}$ & $\mathrm{V}$ & $\mathrm{V}$ & $\mathrm{V}$ & $\mathrm{V}$ & $\mathrm{V}$ & $\mathrm{V}$ & $\mathrm{X}$ & $\mathrm{V}$ & $\mathrm{V}$ & $\bar{X}$ & $\mathrm{X}$ \\
\hline 3 & SIS-3 & $\mathrm{V}$ & $\mathrm{V}$ & $\mathrm{V}$ & $\mathrm{V}$ & $\mathrm{V}$ & $\mathrm{V}$ & $\mathrm{V}$ & $\mathrm{V}$ & $\mathrm{V}$ & $\mathrm{V}$ & $\mathrm{V}$ & $\mathrm{V}$ & $\mathrm{V}$ & $\mathrm{V}$ & $\mathrm{X}$ & $\mathrm{X}$ \\
\hline 4 & SIS-4 & $\mathrm{V}$ & $\mathrm{V}$ & $\mathrm{V}$ & $\mathrm{V}$ & $\mathrm{V}$ & V & $\mathrm{V}$ & $\mathrm{V}$ & $\mathrm{V}$ & $\mathrm{V}$ & $\mathrm{V}$ & $\mathrm{V}$ & $\mathrm{V}$ & $\mathrm{V}$ & $\mathrm{X}$ & $\mathrm{X}$ \\
\hline 5 & SIS-5 & $\mathrm{V}$ & $\mathrm{V}$ & $\mathrm{V}$ & $\mathrm{V}$ & $\mathrm{V}$ & $\mathrm{V}$ & $\mathrm{V}$ & $\mathrm{V}$ & $\mathrm{V}$ & $\mathrm{V}$ & $X$ & $\mathrm{~V}$ & $\mathrm{~V}$ & $\mathrm{~V}$ & $\mathrm{X}$ & $\mathrm{X}$ \\
\hline 6 & SIS-6 & $\mathrm{V}$ & $\mathrm{V}$ & $\mathrm{V}$ & $\mathrm{V}$ & $\mathrm{V}$ & V & $\bar{V}$ & $\mathrm{X}$ & $\mathrm{V}$ & $\mathrm{V}$ & $\mathrm{V}$ & $\mathrm{V}$ & $\mathrm{V}$ & $\mathrm{V}$ & $X$ & $X$ \\
\hline 7 & SIS-7 & V & $\mathrm{V}$ & $\bar{V}$ & $\mathrm{~V}$ & $\mathrm{~V}$ & V & $\bar{V}$ & $\mathrm{~V}$ & $\mathrm{~V}$ & $\mathrm{~V}$ & $\bar{X}$ & $\mathrm{~V}$ & $\mathrm{~V}$ & $\mathrm{~V}$ & $\bar{X}$ & $\mathrm{X}$ \\
\hline 8 & SIS-8 & $\mathrm{V}$ & $\mathrm{V}$ & $\mathrm{V}$ & $\mathrm{V}$ & $X$ & V & $\mathrm{V}$ & $\mathrm{V}$ & V & V & V & V & V & V & $\mathrm{X}$ & $X$ \\
\hline 9 & SIS-9 & $\mathrm{V}$ & $\mathrm{V}$ & $\mathrm{V}$ & $\mathrm{V}$ & $\mathrm{V}$ & V & $X$ & $\mathrm{~V}$ & V & $\mathrm{V}$ & $X$ & $\mathrm{~V}$ & V & $\mathrm{V}$ & $\mathrm{X}$ & $X$ \\
\hline 10 & SIS-10 & V & $\mathrm{V}$ & $\mathrm{V}$ & $\mathrm{V}$ & V & $\mathrm{V}$ & $X$ & V & V & V & $X$ & V & V & V & $X$ & $X$ \\
\hline 11 & SIS-11 & $\mathrm{V}$ & $\mathrm{V}$ & $\mathrm{V}$ & $\mathrm{V}$ & $\mathrm{V}$ & V & $X$ & $X$ & $\mathrm{~V}$ & V & V & $X$ & V & $\mathrm{V}$ & V & $X$ \\
\hline 12 & SIS-12 & $\mathrm{V}$ & $\mathrm{V}$ & $\mathrm{V}$ & $\mathrm{V}$ & $\mathrm{V}$ & $\mathrm{V}$ & $\mathrm{V}$ & $\mathrm{V}$ & $\mathrm{V}$ & $\mathrm{V}$ & $\mathrm{V}$ & $\mathrm{V}$ & $\mathrm{V}$ & $\mathrm{V}$ & $X$ & $X$ \\
\hline 13 & SIS-13 & $\mathrm{V}$ & $\mathrm{V}$ & $\mathrm{V}$ & $\mathrm{V}$ & $\mathrm{V}$ & V & $\mathrm{V}$ & $\mathrm{V}$ & $\mathrm{V}$ & $\mathrm{V}$ & $\mathrm{V}$ & $\mathrm{V}$ & $\mathrm{V}$ & $\mathrm{V}$ & $\mathrm{X}$ & $X$ \\
\hline 14 & SIS-14 & $\mathrm{V}$ & $\mathrm{V}$ & $\mathrm{V}$ & $\mathrm{V}$ & $\mathrm{V}$ & V & $\mathrm{V}$ & $\mathrm{V}$ & $\mathrm{V}$ & $\mathrm{V}$ & $\mathrm{V}$ & $\mathrm{X}$ & $\mathrm{V}$ & $\mathrm{V}$ & $\mathrm{X}$ & $X$ \\
\hline 15 & SIS-15 & $\mathrm{V}$ & $\mathrm{V}$ & $\mathrm{V}$ & $\mathrm{V}$ & $\mathrm{V}$ & V & $\mathrm{X}$ & $\mathrm{V}$ & $\mathrm{V}$ & $\mathrm{V}$ & $\mathrm{V}$ & $X$ & $\mathrm{~V}$ & $\mathrm{~V}$ & $X$ & $X$ \\
\hline 16 & SIS-16 & $\mathrm{V}$ & $\mathrm{V}$ & $\mathrm{V}$ & $\mathrm{V}$ & $\mathrm{V}$ & $\mathrm{V}$ & $\mathrm{V}$ & $\mathrm{V}$ & $\mathrm{V}$ & $\mathrm{V}$ & $\mathrm{V}$ & $X$ & $\mathrm{~V}$ & $\mathrm{~V}$ & $X$ & $X$ \\
\hline 17 & SIS-17 & $\mathrm{V}$ & $\mathrm{V}$ & $\mathrm{V}$ & $\mathrm{V}$ & $\mathrm{V}$ & $\mathrm{V}$ & $X$ & $X$ & $\mathrm{~V}$ & $\mathrm{~V}$ & $\mathrm{~V}$ & $\mathrm{~V}$ & $\mathrm{~V}$ & $\mathrm{~V}$ & $\mathrm{X}$ & $X$ \\
\hline 18 & SIS-18 & $\mathrm{V}$ & $\mathrm{V}$ & $\mathrm{V}$ & $\mathrm{V}$ & $\mathrm{V}$ & V & $\mathrm{V}$ & $\mathrm{V}$ & $\mathrm{V}$ & $\mathrm{V}$ & $\mathrm{V}$ & $\mathrm{V}$ & $\mathrm{V}$ & $\mathrm{V}$ & $\mathrm{X}$ & $X$ \\
\hline 19 & SIS-19 & $\mathrm{V}$ & $\mathrm{V}$ & $\mathrm{V}$ & $\mathrm{V}$ & $\mathrm{V}$ & V & $\mathrm{V}$ & $\mathrm{V}$ & $\mathrm{V}$ & V & $\mathrm{V}$ & $X$ & $\mathrm{~V}$ & V & $\mathrm{V}$ & $X$ \\
\hline 20 & SIS-20 & V & V & $\mathrm{V}$ & $\mathrm{V}$ & V & V & $\mathrm{V}$ & V & V & V & V & V & V & V & $X$ & $X$ \\
\hline 21 & SIS-21 & $\mathrm{V}$ & $\mathrm{V}$ & $\mathrm{V}$ & $\mathrm{V}$ & $\mathrm{V}$ & $\mathrm{V}$ & $\mathrm{V}$ & $\mathrm{V}$ & V & V & V & V & V & V & $\mathrm{X}$ & $X$ \\
\hline 22 & SIS-22 & $\mathrm{V}$ & $\mathrm{V}$ & $\mathrm{V}$ & $\mathrm{V}$ & $\mathrm{V}$ & V & $\mathrm{V}$ & $\mathrm{V}$ & $\mathrm{V}$ & V & $\mathrm{V}$ & $X$ & $\mathrm{~V}$ & V & $\mathrm{X}$ & $X$ \\
\hline 23 & SIS-23 & $\mathrm{V}$ & $\mathrm{V}$ & $\mathrm{V}$ & $\mathrm{V}$ & $\mathrm{V}$ & $\mathrm{V}$ & $\mathrm{V}$ & $\mathrm{V}$ & $\mathrm{V}$ & $\mathrm{V}$ & $\mathrm{V}$ & $\mathrm{V}$ & $\mathrm{V}$ & $\mathrm{V}$ & $X$ & $\mathrm{X}$ \\
\hline 24 & SIS-24 & $\mathrm{V}$ & $\mathrm{X}$ & $\mathrm{V}$ & $\mathrm{V}$ & $\mathrm{V}$ & V & $X$ & $\mathrm{~V}$ & $\mathrm{~V}$ & $\mathrm{~V}$ & $\mathrm{~V}$ & $\mathrm{~V}$ & $\mathrm{~V}$ & $\mathrm{~V}$ & $\mathrm{X}$ & $X$ \\
\hline 25 & SIS-25 & $\mathrm{V}$ & $\mathrm{V}$ & $\mathrm{V}$ & $\mathrm{V}$ & $\mathrm{V}$ & $\mathrm{V}$ & $X$ & $\mathrm{~V}$ & $\mathrm{~V}$ & $\mathrm{~V}$ & $\mathrm{~V}$ & $\mathrm{~V}$ & $\mathrm{~V}$ & $\mathrm{~V}$ & $X$ & $X$ \\
\hline 26 & SIS-26 & $\mathrm{V}$ & $\mathrm{V}$ & $\mathrm{V}$ & $\mathrm{V}$ & $\mathrm{V}$ & $\mathrm{V}$ & $X$ & $\mathrm{~V}$ & $\mathrm{~V}$ & $\mathrm{~V}$ & $\mathrm{~V}$ & $\mathrm{~V}$ & $\mathrm{~V}$ & $\mathrm{~V}$ & $X$ & $X$ \\
\hline 27 & SIS-27 & $\mathrm{V}$ & $\mathrm{V}$ & $\mathrm{V}$ & $\mathrm{V}$ & $\mathrm{V}$ & $\mathrm{V}$ & $\mathrm{V}$ & $\mathrm{V}$ & $\mathrm{V}$ & $\mathrm{V}$ & $\mathrm{V}$ & $\mathrm{V}$ & $\mathrm{V}$ & $\mathrm{V}$ & $\mathrm{X}$ & $\mathrm{X}$ \\
\hline 28 & SIS-28 & $\mathrm{V}$ & $\mathrm{V}$ & $\mathrm{V}$ & $\mathrm{V}$ & $\mathrm{V}$ & $\mathrm{V}$ & $\mathrm{V}$ & $\mathrm{V}$ & $\mathrm{V}$ & $\mathrm{V}$ & $\mathrm{V}$ & $\mathrm{V}$ & $\mathrm{V}$ & $\mathrm{V}$ & X & $X$ \\
\hline
\end{tabular}




\begin{tabular}{|c|c|c|c|c|c|c|c|c|c|c|c|c|c|c|c|c|c|c|}
\hline 29 & \multicolumn{2}{|c|}{ SIS-29 } & V & V & V & V & V & V & V & V & V & V & V & V & V & V & X & X \\
\hline 30 & \multicolumn{2}{|c|}{ SIS-30 } & $\mathrm{V}$ & $\mathrm{V}$ & $\mathrm{V}$ & $\mathrm{V}$ & $\mathrm{V}$ & $\mathrm{V}$ & $\bar{X}$ & $\mathrm{~V}$ & $\mathrm{~V}$ & $\mathrm{~V}$ & $\mathrm{~V}$ & $\mathrm{~V}$ & $\mathrm{~V}$ & $\mathrm{~V}$ & $\mathrm{X}$ & $\mathrm{X}$ \\
\hline \multicolumn{3}{|c|}{ Kelengkapan } & 30 & 29 & 30 & 29 & 29 & 30 & 21 & 26 & 30 & 30 & 26 & 23 & 30 & 30 & 2 & 0 \\
\hline \multicolumn{19}{|c|}{ Keterangan: $\quad \mathrm{v}=$ ada $\quad \mathrm{x}=$ tidak ada } \\
\hline & \multicolumn{4}{|c|}{ A Kop Surat } & $\mathrm{e}$ & \multicolumn{4}{|c|}{ Hal Surat } & $\mathrm{i}$ & \multicolumn{3}{|c|}{ Paragraf Isi } & $\mathrm{m}$ & \multicolumn{4}{|c|}{$\begin{array}{l}\text { Nama Penanda } \\
\text { Tangan }\end{array}$} \\
\hline & B & \multicolumn{3}{|c|}{ Tanggal Surat } & $f$ & \multicolumn{4}{|c|}{ Alamat Tujuan } & $\mathrm{j}$ & \multicolumn{3}{|c|}{$\begin{array}{l}\text { Paragraf } \\
\text { Penutup }\end{array}$} & $\mathrm{n}$ & \multicolumn{4}{|c|}{$\begin{array}{l}\text { Jabatan Penanda } \\
\text { Tangan }\end{array}$} \\
\hline & $\mathrm{C}$ & \multicolumn{3}{|c|}{ Nomor Surat } & $\mathrm{g}$ & \multicolumn{4}{|c|}{ Salam Pembuka } & $\mathrm{k}$ & \multicolumn{3}{|c|}{ Salam Penutup } & o & \multicolumn{4}{|c|}{ Tembusan } \\
\hline & $\mathrm{D}$ & \multicolumn{3}{|c|}{ Lamp. Surat } & h & \multicolumn{4}{|c|}{$\begin{array}{l}\text { Paragraf } \\
\text { Pembuka }\end{array}$} & 1 & \multicolumn{3}{|c|}{ Tanda Tangan } & $\mathrm{p}$ & \multicolumn{4}{|c|}{ Inisial } \\
\hline
\end{tabular}

Tabel 1 di atas menunjukkan bahwa dari segi kelengkapan bagian-bagian surat (struktur), surat dinas yang ditulis siswa cenderung lengkap. Kelengkapan tersebut terlihat dari (1) semua siswa menulis kop surat, (2) 29 dari 30 siswa menulis tanggal surat, (3) semua siswa menulis nomor surat, (4) 29 siswa membuat lampiran surat, (5) 29 siswa menulis hal surat, (6) semua siswa menulis alamat tujuan surat, (7) 21 siswa menulis salam pembuka, (8) 26 siswa menulis paragraf pembuka, (9) semua siswa menulis isi surat, (10) semua siswa menulis penutup surat, (11) 26 siswa menulis salam penutup, (12) 23 siswa menulis tanda tangan, (13) 30 siswa menulis nama penanda tangan, (14) semua siswa menulis jabatan penanda tangan, (15) siswa menulis tembusan, dan (16) tidak ada siswa yang menulis inisial. Bila dipresentasekan, dari segi kelengkapan struktur, surat-surat yang dibuat siswa SMK PAB 3 ME terlihat pada tabel di bawah ini.

Tabel 2: Persentase Kelengkapan Bagian-Bagian Surat yang Ditulis Siwa SMK PAB 3ME

\begin{tabular}{|c|l|c|}
\hline No. & \multicolumn{1}{|c|}{ Bagian-Bagian Surat } & Persentase (\%) \\
\hline 1. & Kop Surat & 100 \\
\hline 2. & Tanggal Surat & 96,67 \\
\hline 3. & Nomor Surat & 100 \\
\hline 4. & Lampiran Surat & 96,67 \\
\hline 5. & Hal Surat & 96,67 \\
\hline 6. & Alamat Tujuan Surat & 100 \\
\hline 7. & Salam Pembuka & 70 \\
\hline 8. & Paragraf Pembuka & 86,67 \\
\hline 9. & Isi Surat & 100 \\
\hline 10. & Penutup Surat & 100 \\
\hline 11. & Salam Penutup & 86,67 \\
\hline 12. & Tanda Tangan & 76,67 \\
\hline 13. & Nama Penanda Tangan & 100 \\
\hline 14. & Jabatan Penanda Tangan & 100 \\
\hline 15. & Tembusan & 2,99 \\
\hline 16. & Inisial & 0 \\
\hline
\end{tabular}

Tabel 2 di atas memperlihatkan bahwa(1) semua surat yang ditulis siswa sudah memiliki kop, nomor, alamat, isi, penutup, nama penadanda tangan, dan jabatan penanda tangan; (2) ada sedikit surat yang tidak memiliki tanggal surat — termasuk bagian yang sangat penting —; (3) lampiran, tembusan, dan inisial merupakan hal yang tidak wajib sehingga tidak menjadi 
perhatian; (4) masih ada surat yang tidak memiliki paragraf pembuka dan tanda tangan, padahal kedua komponen tersebut bersifat wajib.

Kelengkapan bagian-bagian surat ini sangat penting dalam sebuah surat dinas. Akan tetapi, lengkapnya bagian-bagian surat tidak menjamin surat yang ditulis tersebut baik. Untuk itu, ada komponen lain yang harus diperhatikan dalam sebuah surat. Komponen yang dimaksud adalah ketepatan atau kesesuaian isi bagian-bagian surat tersebut.

\subsubsection{Ketepatan Penulisan Bagian-Bagian Surat oleh Siswa Kelas XI SMK PAB 3 ME}

Hasil penelitian ini menunjukkan bahwa surat-surat yang ditulis siswa kelas XI SMK PAB 3 ME belum tepat dari segi isi meskipun cenderung lengkap dari segi struktur. Hal itu terlihat pada tabel 3 di bawah ini.

Tabel 3: Ketepatan Penulisan Bagian-Bagian Surat oleh Siswa Kelas XI SMK PAB 3 ME

\begin{tabular}{|c|c|c|c|c|c|c|c|c|c|c|c|c|c|c|c|c|c|}
\hline \multirow[t]{2}{*}{ No. } & \multirow{2}{*}{$\begin{array}{l}\text { Kode } \\
\text { Siswa } \\
\end{array}$} & \multicolumn{16}{|c|}{ Bagian-Bagian Surat } \\
\hline & & $\mathbf{a}$ & b & c & d & e & $\mathbf{f}$ & $\mathbf{g}$ & $\mathbf{h}$ & $\mathbf{i}$ & $\mathbf{j}$ & $\mathbf{k}$ & l & $\mathbf{M}$ & $\mathbf{n}$ & $\mathbf{0}$ & $\mathbf{p}$ \\
\hline 1 & SIS-1 & $\mathrm{X}$ & $\mathrm{X}$ & $\mathrm{V}$ & $\mathrm{V}$ & $\mathrm{X}$ & $\mathrm{X}$ & $\mathrm{V}$ & $\mathrm{V}$ & $x$ & $\mathrm{X}$ & $\mathrm{V}$ & $\mathrm{V}$ & $\mathrm{X}$ & $\mathrm{V}$ & $\mathrm{X}$ & \\
\hline 2 & SIS-2 & $\mathrm{X}$ & $\mathrm{X}$ & $\mathrm{V}$ & $\mathrm{V}$ & $\mathrm{X}$ & $\mathrm{V}$ & $\mathrm{V}$ & $\mathrm{V}$ & $\mathrm{V}$ & $\mathrm{X}$ & $\mathrm{V}$ & $\mathrm{X}$ & $\mathrm{X}$ & $x$ & $\mathrm{X}$ & \\
\hline 3 & SIS-3 & $\mathrm{X}$ & $\mathrm{V}$ & $\mathrm{V}$ & V & $\mathrm{X}$ & V & $\mathrm{V}$ & $\mathrm{V}$ & V & $\mathrm{V}$ & $\mathrm{V}$ & $\mathrm{V}$ & $\mathrm{X}$ & $x$ & $X$ & \\
\hline 4 & SIS-4 & $\mathrm{X}$ & $\mathrm{X}$ & $\mathrm{V}$ & $\mathrm{X}$ & $\mathrm{V}$ & $\mathrm{X}$ & $\mathrm{V}$ & $\mathrm{V}$ & $x$ & $\mathrm{X}$ & $\mathrm{V}$ & V & $\mathrm{X}$ & $\mathrm{V}$ & $X$ & \\
\hline 5 & SIS-5 & $\mathrm{X}$ & $\mathrm{X}$ & $\mathrm{V}$ & $\mathrm{X}$ & V & $\mathrm{X}$ & $X$ & $\mathrm{X}$ & $x$ & $\mathrm{X}$ & $\mathrm{X}$ & $\mathrm{V}$ & $X$ & $x$ & $X$ & $y$ \\
\hline 6 & SIS-6 & $X$ & $\mathrm{X}$ & $\mathrm{V}$ & $X$ & V & $X$ & $\mathrm{~V}$ & $\mathrm{~V}$ & $x$ & $X$ & $\mathrm{~V}$ & $\mathrm{~V}$ & $X$ & $\mathrm{~V}$ & $X$ & \\
\hline 7 & SIS-7 & $X$ & $X$ & $\mathrm{~V}$ & $\mathrm{~V}$ & $X$ & $X$ & $\mathrm{~V}$ & $\mathrm{~V}$ & $x$ & $X$ & $\mathrm{X}$ & $\mathrm{V}$ & $X$ & $\mathrm{~V}$ & $X$ & $x$ \\
\hline 8 & SIS-8 & $\mathrm{X}$ & $\mathrm{X}$ & $\mathrm{V}$ & $\mathrm{V}$ & $X$ & $X$ & $\mathrm{~V}$ & $\mathrm{~V}$ & $x$ & $X$ & $\mathrm{~V}$ & $\mathrm{~V}$ & $\mathrm{X}$ & $\mathrm{V}$ & $X$ & \\
\hline 9 & SIS-9 & $X$ & $\mathrm{X}$ & $\mathrm{V}$ & $\mathrm{V}$ & $X$ & $X$ & $\mathrm{~V}$ & $\mathrm{~V}$ & $x$ & $\mathrm{~V}$ & $\mathrm{~V}$ & $\mathrm{~V}$ & $X$ & $\mathrm{~V}$ & $X$ & \\
\hline 10 & SIS-10 & $X$ & $\mathrm{X}$ & $\mathrm{V}$ & $X$ & $\mathrm{~V}$ & $\mathrm{X}$ & V & $X$ & $x$ & $\mathrm{X}$ & $\mathrm{V}$ & $\mathrm{V}$ & $\mathrm{X}$ & $x$ & $X$ & $X$ \\
\hline 11 & SIS-11 & $X$ & $\mathrm{X}$ & $\mathrm{V}$ & $X$ & $X$ & $X$ & $x$ & $X$ & $x$ & $\mathrm{X}$ & $\mathrm{V}$ & $\mathrm{X}$ & $\mathrm{X}$ & $x$ & $\mathrm{X}$ & X \\
\hline 12 & SIS-12 & $\mathrm{X}$ & $\mathrm{X}$ & $\mathrm{V}$ & $X$ & $\mathrm{~V}$ & $X$ & $x$ & $\mathrm{X}$ & $x$ & $\mathrm{~V}$ & $\mathrm{~V}$ & $\mathrm{~V}$ & $\mathrm{X}$ & $x$ & $X$ & X \\
\hline 13 & SIS-13 & $X$ & $X$ & $\mathrm{~V}$ & $X$ & $X$ & $X$ & $\mathrm{~V}$ & $X$ & $x$ & $x$ & $\mathrm{~V}$ & $\mathrm{~V}$ & $X$ & $x$ & $X$ & $\bar{X}$ \\
\hline 14 & SIS-14 & $X$ & $X$ & $\mathrm{~V}$ & $X$ & $X$ & $X$ & $\mathrm{~V}$ & $\mathrm{~V}$ & $x$ & $\mathrm{~V}$ & $\mathrm{~V}$ & $X$ & $X$ & $x$ & $X$ & X \\
\hline 15 & SIS-15 & $X$ & $\mathrm{X}$ & $\mathrm{V}$ & $X$ & $\mathrm{~V}$ & $X$ & $\mathrm{X}$ & $\mathrm{X}$ & $x$ & $x$ & $\mathrm{~V}$ & $\mathrm{X}$ & $\mathrm{X}$ & $x$ & $X$ & $\mathrm{X}$ \\
\hline 16 & SIS-16 & $X$ & $X$ & $\mathrm{~V}$ & $X$ & $X$ & $X$ & $\mathrm{X}$ & $\mathrm{X}$ & $\mathrm{V}$ & $\mathrm{V}$ & $X$ & $\mathrm{X}$ & $X$ & $x$ & $X$ & X \\
\hline 17 & SIS-17 & $X$ & $X$ & $\mathrm{~V}$ & $X$ & $X$ & $X$ & $\mathrm{X}$ & $\mathrm{X}$ & $\mathrm{V}$ & $\mathrm{V}$ & $\mathrm{V}$ & $\mathrm{V}$ & $X$ & $\mathrm{~V}$ & $X$ & X \\
\hline 18 & SIS-18 & $X$ & $X$ & $\mathrm{~V}$ & $X$ & $\mathrm{~V}$ & $X$ & $\mathrm{~V}$ & $\mathrm{~V}$ & $x$ & $X$ & $\mathrm{~V}$ & V & $X$ & $X$ & $X$ & X \\
\hline 19 & SIS-19 & $X$ & $\mathrm{X}$ & $\mathrm{V}$ & $X$ & $X$ & $\mathrm{~V}$ & $\mathrm{~V}$ & $\mathrm{~V}$ & $x$ & $\mathrm{~V}$ & $\mathrm{~V}$ & $X$ & $X$ & $\mathrm{~V}$ & $X$ & X \\
\hline 20 & SIS-20 & $\mathrm{X}$ & $\mathrm{X}$ & $\mathrm{V}$ & $X$ & $\mathrm{~V}$ & $\mathrm{~V}$ & $\mathrm{~V}$ & $\mathrm{~V}$ & $x$ & $X$ & $\mathrm{~V}$ & $\mathrm{~V}$ & $X$ & $\mathrm{~V}$ & $X$ & X \\
\hline 21 & SIS-21 & $X$ & $\mathrm{X}$ & $\mathrm{V}$ & $X$ & $X$ & $X$ & $\mathrm{~V}$ & $\mathrm{~V}$ & $x$ & $\mathrm{X}$ & $\mathrm{V}$ & $\mathrm{V}$ & $X$ & $X$ & $X$ & X \\
\hline 22 & SIS-22 & $X$ & $X$ & $\mathrm{~V}$ & $X$ & $\mathrm{~V}$ & $\mathrm{~V}$ & $\mathrm{~V}$ & $\mathrm{~V}$ & $x$ & $X$ & $\mathrm{~V}$ & $X$ & $X$ & $X$ & $X$ & $\bar{X}$ \\
\hline 23 & SIS-23 & $X$ & $\mathrm{X}$ & $\mathrm{V}$ & $X$ & V & $X$ & X & $X$ & $\mathrm{~V}$ & $\mathrm{X}$ & $\mathrm{V}$ & $\mathrm{V}$ & $\mathrm{X}$ & $\mathrm{V}$ & $\mathrm{X}$ & X \\
\hline 24 & SIS-24 & $\mathrm{X}$ & $\mathrm{X}$ & $\mathrm{V}$ & $\mathrm{V}$ & $X$ & $\mathrm{X}$ & $\mathrm{X}$ & $\mathrm{X}$ & $x$ & $\mathrm{X}$ & $\mathrm{V}$ & $\mathrm{V}$ & $\mathrm{X}$ & $\mathrm{V}$ & $X$ & $\mathrm{X}$ \\
\hline 25 & SIS-25 & $\mathrm{X}$ & $\mathrm{X}$ & $\mathrm{V}$ & $\mathrm{V}$ & $X$ & $X$ & $\mathrm{~V}$ & $\mathrm{~V}$ & $x$ & $\mathrm{X}$ & $\mathrm{V}$ & $\mathrm{V}$ & $\mathrm{X}$ & $\mathrm{V}$ & $X$ & $\mathrm{X}$ \\
\hline 26 & SIS-26 & $X$ & $X$ & $\mathrm{~V}$ & $X$ & $X$ & $X$ & $\mathrm{X}$ & $X$ & $\mathrm{~V}$ & $X$ & $x$ & $\mathrm{~V}$ & $X$ & $\mathrm{~V}$ & $X$ & $\mathrm{X}$ \\
\hline 27 & SIS-27 & $X$ & $\mathrm{X}$ & $\mathrm{V}$ & $\mathrm{V}$ & $X$ & $X$ & $X$ & $X$ & $X$ & $X$ & $x$ & $\mathrm{~V}$ & $X$ & $\mathrm{~V}$ & $X$ & $\mathrm{X}$ \\
\hline 28 & SIS-28 & $X$ & $\mathrm{X}$ & $\mathrm{V}$ & $x$ & $X$ & $\mathrm{~V}$ & $X$ & $\mathrm{X}$ & $x$ & $X$ & $x$ & $\mathrm{~V}$ & $X$ & $\mathrm{~V}$ & $X$ & X \\
\hline 29 & SIS-29 & $\mathrm{X}$ & $\mathrm{X}$ & $\mathrm{V}$ & $\mathrm{V}$ & $X$ & $X$ & V & $\mathrm{V}$ & $x$ & $X$ & $x$ & $\mathrm{~V}$ & $X$ & $\mathrm{~V}$ & $X$ & X \\
\hline 30 & SIS-30 & $X$ & $X$ & $\mathrm{~V}$ & $x$ & $X$ & $X$ & $\mathrm{~V}$ & $\mathrm{~V}$ & $x$ & $X$ & $x$ & $\mathrm{~V}$ & $X$ & $\mathrm{~V}$ & $X$ & X \\
\hline Jml. & k. tepat & 30 & 29 & 0 & 19 & 20 & 24 & 11 & 13 & 24 & 23 & 8 & 7 & 30 & 12 & 2 & 30 \\
\hline
\end{tabular}

Keterangan: $\mathrm{V}=$ tepat $\quad \mathrm{X}=$ tidak tepat 

a Kop Surat
e Hal Surat
i Paragraf Isi
m Nama Penanda Tangan
b Tanggal Surat $f$ Alamat Tujuan j Paragraf
Penutup
n Jabatan Penanda
Tangan
c Nomor Surat
g Salam Pembuka k Salam Penutup
d Lamp. Surat
h Paragraf
Tanda Tangan
o Tembusan
Pembuka

Tabel 3 di atas memperlihatkan bahwa (1) semua kop surat tidak ditulis dengan tepat, (2) 29 tanggal surat ditulis tidak tepat, (3) semua nomor surat ditulis dengan tepat, (4) 19 lampiran surat ditulis tidak tepat, (5) 20 hal surat ditulis tidak tepat, (6) 24 alamat surat ditulis tidak tepat, (7) 11 salam pembuka surat ditulis tidak tepat, (8) 13 paragraf pembuka surat ditulis tidak tepat, (9) 24 isi surat ditulis tidak tepat, (10) 23 isi surat ditulis tidak tepat, (11) 8 penutup surat ditulis tidak tepat, (12) 7 tanda tangan surat tidak ditulis, (13) semua nama penanda tangan surat ditulis tidak tepat, (14) 12 jabatan penanda tangan surat ditulis tidak tepat, (15) tembusan surat ditulis tidak tepat, (16) tidak ada siswa membuat inisial. Untuk lebih jelas, berikut ini disajikan perbandingan antara ketepatan dan ketidaktepatan penulisan bagian-bagian surat yang ditulis siswa SMK PAB 3 ME.

\section{Tabel 4: Perbandingan Ketepatan dan Ketidaktepatan Penulisan Bagian-bagian Surat oleh Siswa SMK PAB 3 ME}

\begin{tabular}{|c|l|c|c|}
\hline No. & \multicolumn{1}{|c|}{ Bagian-Bagian Surat } & Ketepatan & Ketidaktepatan \\
\hline 1. & Kop Surat & 0 & 30 \\
\hline 2. & Tanggal Surat & 1 & 29 \\
\hline 3. & Nomor Surat & 30 & 0 \\
\hline 4. & Lampiran Surat & 11 & 19 \\
\hline 5. & Hal Surat & 10 & 20 \\
\hline 6. & Alamat Tujuan Surat & 6 & 24 \\
\hline 7. & Salam Pembuka & 19 & 11 \\
\hline 8. & Paragraf Pembuka & 17 & 13 \\
\hline 9. & Isi Surat & 6 & 24 \\
\hline 10. & Penutup Surat & 7 & 23 \\
\hline 11. & Salam Penutup & 22 & 8 \\
\hline 12. & Tanda Tangan & 23 & 30 \\
\hline 13. & Nama Penanda Tangan & 0 & 12 \\
\hline 14. & Jabatan Penanda Tangan & 18 & 30 \\
\hline 15. & Tembusan & 0 & 62,22 \\
\hline 16. & Inisial & 37,78 & \\
\hline & Persentase & \multicolumn{2}{c|}{} \\
\hline
\end{tabular}

Tabel 4 di atas menunjukkan persentase ketepatan lebih rendah $(37,78 \%)$ dibandingkan persentase ketidaktepatan (62,22\%). secara rinci, ketidaktepatan tersebut didominasi oleh bagian-bagian yang sangat penting, yakni (1) kop surat, (2) tanggal surat, (3) lampiran surat, (4) hal surat, (5) alamat tujuan surat, (6) isi surat, (7) penutup surat, dan (8) nama penanda tangan surat. Sementara itu, ketepatan hanya didominasi bagian (1) penulisan nomor surat, (2) paragraf pembuka, (3) salam penutup, dan (4) tanda tangan. Perlu 
disampaikan di sini bahwa pada bagian tembusan, hanya dua surat yang memuat hal itu, namun keduanya memilii penulisan tidak tepat.

\subsubsection{Kesalahan Penulisan Surat yang Dilakukan Siswa Kelas XI SMK PAB 3 ME}

Kesalahan umum penulisan surat yang dilakukan siswa kelas XI SMK PAB adalah berikut ini.

(1) Penulisan Kop Surat

Pada surat yang ditulis siswa ditemukan sejumlah kesalahan penulisan kop surat. Kesalahan tersebut meliputi:

(a) kesalahan penulisan nama instansi/lembaga, yang dituliskan tanpa menggunakan huruf kapital, misalnya "Dinas Pendidikan Pemuda dan Olahraga Kabupaten Tenggal";

(b) kesalahan penulisan kata Jalan, Telepon, Faksimile, yang dituliskan Jl., Jln., Telp., Tlp, Telp, Fax;

(c) kesalahan penulisan nama geografis, misalnya Ogan, Kalimatan Tengah, dan Deliserdang yang dituliskan ogan, Kalimantan tengah, dan Deli Serdang;

(d) kesalahan penggunaan tanda baca, misalnya ...Medan, Sumatera Utara dan Deliserdang yang dituliskan...Medan-Sumatera Utara, Deli Serdang.;

(e) kesalahan dalam menggunakan garis tebal di bawah kop surat.

(2) Penulisan Tanggal Surat

Mayoritas surat yang ditulis siswa menyertakan nama tempat dalam penulisan tanggal surat, padahal surat yang ditulis memiliki kop surat. Contoh, Tembung, 27 April 2016; Surabaya, 11 Oktober 2016; Medan, 25 Mei 2018.

(3) Penulisan Lampiran Surat

Sebaian besar surat yang ditulis siswa mencantumkan kata "Lamp. atau Lampiran" dalam naskah surat, meskipun surat yang ditulis tidak memiliki lampiran, misalnya Lamp. : -, Lampiran: -. Selain itu, ada juga ditemukan surat yang meletakkan lampiran di bawah hal atau perihal.

(4) Penulisan Hal atau Perihal

Dalam surat yang ditulis siswa ditemukan kesalahan penulisan hal atau perihal. Kesalahan itu terlihat di bawah ini.

(a) Menuliskan setiap kata pada hal dengan huruf kapital, misalnya Permohonan Rekomendasi.

(b) Hal dituliskan di atas kata Lampiran.

(c) Hal ditulis terlalu panjang, contohnya, "Instruksi Penanaman Pohon Di Lingkungan Sekolah".

(d) Hal ditulis dengan menggunakan huruf kapital semua, misalnya "LAPORAN ASET".

(5) Penulisan Alamat Tujuan

Penulisan alamat tujuan yang tidak tepat dalam surat resmi yang ditulis siswa berupa hal-hal berikut:

(a) alamat tujuan surat diawali dengan kata Kepada,

(b) penulisan Yth. Yang tidak tepat (Yth),

(c) penggunaan huruf kapital yang tidak tepat, misalnya dinas pertamanan, Di tempat,

(d) penggunaan tanda titik di akhir alamat, misalnya, di Tempat., di Medan. 
(6) Penulisan Salam Pembuka

Kesalahan umum yang ditemukan dalam surat dinas yang ditulis siswa kelas XI SMK PAB 3 ME adalah sebagai berikut:

(a) tidak menggunakan salam pembuka,

(b) tidak menggunakan tanda baca koma (,) setelah Dengan hormat,

(c) penulisan bentuk sapaan yang tidak tepat, misalnya, bapak/ibu/saudara/saudari ...,

(7) Penulisan Pembuka Surat

Ada berbagai kesalahan yang ditemukan dalam surat dinas yang ditulis siswa. Kesalahan tersebut, contohnya, adalah "Menghubungi surat Saudara Nomor: 010/SNSPS/P.Fisika/V/2018....”. Kesalahan tersebut dapat ditinjau dari segi bahasa, isi, kelogisan, keefektifan, daln lain-lain. Jelas-jelas kalimat pembukan surat tersebut tidak tepat.

(8) Penulisan Isi Surat

Ditemukan banyak kesalahan yang terdapat dalam surat yang ditulis siswa dari segi

isinya. Kesalahan tersebut, sebagai contoh, terlihat pada kutipan di bawah ini.

... pelaksanaan hari menanam pohon Indonesia dan menanam nasional. Kota

administrasi jakarta selatan menginstruksikan kepada semua Kepala

SMA/SMK negeri/swasta sebagai berikut:

1. pada hari minggu, 26 Desember 2017 pukul 08.00 WIB.

2. Bagi siswa yang tidak punya lahan bisa menggunakan pot.

3. Melaksanakan kebersihan sekolah untuk memberantas sarang nyamuk (PSN) selama lebih kurang 30 menit.

Jelas terlihat bahwa isi surat tersebut tidak koheren. Isi surat juga tidak logis. Bahasa yang digunakan tidak efektif. Ejaan yang digunakan pun tidak tepat.

(9) Penulisan Penutup Surat

Kesalahan penutup surat yang umum ditemukan dalam surat dinas yang ditulis siswa adalah kesalahan dalam menggunakan klitik -nya, seperti Atas perhatiannya, kami menyampaikan terima kasih. Selain itu, penulisan bentuk sapaan juga tidak tepat, seperti bapak/ibu/saudara yang bertindak sebagai sapaan langsung.

(10) Penulisan Nama Pengirim (Penanda Tangan) Surat

Dari 30 buah surat yang ditulis siswa, tidak satu pun penulisan nama pengirim ditulis benar. Kesalahan itu berupa (1) ditulisnya unsur-unsur nama pengirim tidak sesuai dengan kaidah, seperti Muhammad BISRI. SE_yang seharusnya ditulis Muhammad Nasri, S.E.- , (2) ditulisnya gelar akademik pengirim tidak sesuai dengan kaidah, misalnya Aisyah Zahra.M.T, Aidil. MM, dan M. WAHYU PRAYOGI S.P.D, yang seharusnya ditulis Aisyah Zahra, M.T., Aidil, M.M., dan M. Wahyu Prayogi, S.Pd., dan (3) ditulisnya NIP tidak sesuai dengan kaidah, misalnya NIP., Nip, NIP:, dan nip.

(11) Penulisan Tembusan

Dari 30 surat yang ditulis siswa, ada dua surat yang memiliki tembusan. Kedua tembusan surat tersebut memiliki kesalahan dalam penulisan, yakni mencantumkan arsip dan pertinggal sebagai bagian tembusan surat.

\subsection{Pembahasan Hasil Penelitian}

\subsubsection{Kelengkapan Bagian-Bagian Surat yang Ditulis Siswa Kelas XI SMK PAB 3 ME}

Secara umum, semua siswa sudah menulis surat dinas dengan bagian-bagian atau struktur yang lengkap. Kelengkapan bagian-bagian surat ini mutlak diperlukan. Bagian- 
bagian surat dinas itu meliputi (1) kepala surat atau kop surat, (2) tanggal surat, (3) nomor surat, (4) lampiran surat, (5) hal surat, (6) alamat yang dituju, (7) salam pembuka, (8) paragraf pembuka, (9) paragraf isi, (10) paragraf penutup, (11) salam penutup, (12) tanda tangan, (13) nama penanda tangan, (14) jabatan penanda tangan, (5) tembusan, dan (6) inisial (Arifin dan Mustaksim, 2005:34).

Bagian tembusan dan inisial belum menjadi perhatian siswa untuk menulisnya. Hal itu terlihat dari kedua bagian tersebut hampir tidak terdapat dalam surat dinas yang ditulis siswa—bahkan, tidak satu pun naskah surat dinas yang ditulis menmbuat inisial—.

\subsubsection{Ketepatan Penulisan Bagian-Bagian Surat oleh Siswa Kelas XI SMK PAB 3 ME}

Rendahnya ketepatan penulisan bagian-bagian surat $(37,78 \%)$ oleh siswa SMK PAB 3 ME menjadi masalah tersendiri. Artinya, siswa belum mampu menggunakan bahasa yang tepat untuk menyampaikan maksud atau pikiran melalui surat. Padahal, surat merupakan hal yang tidak terpisahkan dalam kehidupan, meskipun zaman semakin canggih.

\subsubsection{Kesalahan Umum Penulisan Surat yang Dilakukan Siswa Kelas XI SMK PAB 3 ME}

Kesalahan umum penulisan surat yang dilakukan siswa SMK PAB 3 ME terdapat pada (1) penulisan kop surat, contohnya nama instansi/lembaga yang dituliskan tanpa menggunakan huruf kapital (Dinas Pendidikan Pemuda dan Olahraga Kabupaten Tenggal); kata Jalan, Telepon, Faksimile, yang dituliskan Jl., Jln., Telp., Tlp, Telp, Fax; (2) penulisan tanggal, Tembung, 27 April 2016 dan Medan, 25 Mei 2018; (3) penulisan lampiran, contohnya kata Lamp. atau Lampiran" pada surat yang tidak memiliki lampiran dan penulisan lampiran yang tidak tepat; (4) penulisan Hal atau Perihal, contohnya Permohonan Rekomendasi; (5) penulisan alamat tujuan, contohnya alamat tujuan surat diawali dengan kata Kepada; (6) penulisan salam pembuka, contohnya sapaan bapak/ibu/saudara/saudari ...; (7) pembuka surat, contohnya "Menghubungi surat Saudara Nomor: 010/SNSPS/P.Fisika/V/2018...."; (8) isi surat, misalnya... pelaksanaan hari menanam pohon Indonesia dan menanam nasional. Kota administrasi jakarta selatan menginstruksikan kepada semua Kepala SMA/SMK negeri/swasta sebagai berikut: (1) pada hari minggu, 26 Desember 2017 pukul 08.00 WIB (bukan instruksi); (9) penutup surat, contohnya Atas perhatiannya, kami menyampaikan terima kasih.; (10) nama pengirim (penanda tangan) surat, contohnya Aisyah Zahra.M.T, Aidil. MM, dan M. WAHYU PRAYOGI S.P.D; (11) tembusan, contohnya arsip dan pertinggal.

\section{Penutup \\ 5.1 Simpulan}

Berdasarkan hasil penelitian dan pembahasan dapat disimpulkan bahwa (1) semua surat dinas yang ditulis siswa memiliki struktur (inti) yang lengkap, mulai dari kop surat hingga nama pengirim surat; (2) ketepatan penulisan bagian-bagian surat dinas yang ditulis siswa sangat rendah, yakni 37,78\%; (3) terdapat sejumlah kesalahan umum yang terdapat dalam surat dinas yang ditulis siswa.

\subsection{Saran}

Penelitian ini mengungkapkan 'secara tidak langsung' kemampuan siswa menulis surat sangat rendah. Untuk itu, diperlukan upaya nyata, terutama bagi guru bahasa Indonesia untuk meningkatkan pemahaman siswa akan surat dinas dan keterampilan siswa menggunakan bahasa Indonesia dalam menulis surat dinas. Siswa tidak hanya dituntut untuk 
mampu memahami struktur surat, tetapi lebih dari itu, siswa juga dituntut untuk mampu mengekspresikan ide dan keinginannya melalui bahasa sebagai pengisi struktur surat dinas tersebut.

\section{Daftar Pustaka}

Arifin, Zainal dan Mustakim. 2005. Bahasa Indonesia bagi Sekretaris. Jakarta: PT Grasindo. Darma, Yoce Aliah dan Kosasih. 2009. Menulis Surat Dinas Lengkap. Bandung: CV Yrama Widya.

Hasnun, Anwar. 2007. Pedoman dan Petunjuk Praktis Karya Tulis. Yogyakarta: Absolut. Silmi, Sikka Mutiara. 2004. Panduan Menulis Surat Lengkap. Yogyakarta: Absolut.

Subyantoro. 2008. Dasar-Dasar Keterampilan Menulis. Semarang: Cipta Prima Nusantara. Triharjanto. 2007. Panduan Menulis Surat. Yogyakarta: Siklus.

Wibowo, Teguh. 2008. Jurus Maut Menguasai Materi Pelajaran Bahasa Indonesia. Yogyakarta: Locus.

Setiawan, O. Djuharie, Suherli, dan Teddy S.K. 2009. Surat-Menyurat Serbaguna Panduan Korespondensi Bahasa Indonesia. Bandung: CV Yrama Widia. 